\title{
Methylothermus thermalis gen. nov., sp. nov., a novel moderately thermophilic obligate methanotroph from a hot spring in Japan
}

Correspondence
Yuri A. Trotsenko
trotsenko@ibpm.pushchino.ru

\author{
Jun Tsubota, ${ }^{1}$ Bulat Ts. Eshinimaev, ${ }^{2}$ Valentina N. Khmelenina ${ }^{2}$ \\ and Yuri A. Trotsenko ${ }^{2}$
${ }^{1}$ Energy and Technology Laboratories, Osaka Gas Co., Ltd, 6-19-9 Torishima Konohana-ku, Osaka 554-0051, Japan \\ ${ }^{2}$ G. K. Skryabin Institute of Biochemistry and Physiology of Microorganisms, Russian Academy \\ of Sciences, 142290 Pushchino, Moscow Region, Russia
}

\section{INTRODUCTION}

Obligate methanotrophs are a highly specialized group of bacteria that utilize methane and methanol as sole carbon and energy sources. They are widespread in nature and inhabit soils, wetlands, fresh and marine waters, lakes and sediments, being mostly neutrophilic and mesophilic

Published online ahead of print on 22 July 2005 as DOI 10.1099/ ijs.0.63691-0.

Abbreviations: ICM, intracytoplasmic membrane; PLFA, phospholipid fatty acid; $\mathrm{pMMO}$ and $\mathrm{sMMO}$, particulate and soluble methane monooxygenase, respectively; RuMP, ribulose monophosphate.

The GenBank/EMBL/DDBJ accession numbers for the 16S rRNA gene sequence and partial sequence of the $p m o A$ gene of Methylothermus thermalis strain $\mathrm{MYHT}^{\top}$ are AY829009 and AY829010, respectively.

A figure showing the oxidation and assimilation of ${ }^{14} \mathrm{C}$-methane by cells of strain MYHT ${ }^{\top}$ is available as supplementary material in IJSEM Online.
(Hanson \& Hanson, 1996). Nevertheless, in the past decade, investigations of extreme environments with high and low $\mathrm{pH}$, temperatures or salinities have led to the discovery of a variety of extremophilic and extremotolerant methanotrophs (Murrell et al., 1998; Trotsenko \& Khmelenina, 2002).

The solubility of $\mathrm{CH}_{4}$ and $\mathrm{O}_{2}$ in aqueous solution drops with increasing temperature, thus limiting growth of methanotrophic bacteria. However, gas solubility in natural waters of low ionic strength $(<100 \mathrm{mM})$ decreases by only one-third when the temperature increases from 30 to $60^{\circ} \mathrm{C}$. This explains the existence of methanotrophs in various habitats with elevated temperatures. The earliest described heat-tolerant methanotroph was Methylococcus capsulatus, which grows at temperatures up to $50{ }^{\circ} \mathrm{C}$ (Foster \& Davis, 1966; Whittenbury et al., 1970). Several other moderately thermophilic and thermotolerant species, including Methylococcus thermophilus, 'Methylococcus ucrainicus', Methylocaldum 
szegediense, Methylocaldum tepidum and Methylocaldum gracile, were subsequently described (Malashenko et al., 1975; Malashenko, 1976; Bodrossy et al., 1995, 1997, 1999; Eshinimaev et al., 2004).

Very recently, a representative of a novel group of truly thermophilic methanotrophs, strain HB, was isolated from Hungarian and Japanese hot springs (Bodrossy et al., 1999), with temperature limits for growth between 40 and $70{ }^{\circ} \mathrm{C}$ and an optimum at $55-62{ }^{\circ} \mathrm{C}$. Strain HB was closely related to the known thermotolerant Methylococcus and Methylocaldum species, as indicated by 16S rRNA and particulate methane monooxygenase ( $p m o A$ ) gene sequence analyses. Strain HB represented a new genus, and the informal name 'Methylothermus' was proposed for this methanotroph (Bodrossy et al., 1999). However, no comparative studies of the phenotypic features of strain $\mathrm{HB}$ with those of known thermophilic and thermotolerant methanotrophs have been performed. Moreover, this organism is no longer extant (K. L. Kovács, personal communication), which prompted our attempts to isolate and characterize thermophilic methanotrophs from a Japanese hot spring. Herein, we describe a novel moderately thermophilic methanotrophic strain.

\section{METHODS}

Sampling. Sediments from a hot spring located in Hyogo, Japan were collected in $15 \mathrm{ml}$ plastic tubes during September 2001, and kept at $4{ }^{\circ} \mathrm{C}$ before use.

Growth conditions. For the enrichment and isolation of methanotrophs, a basal ammonium nitrate mineral salt (ANMS) medium was used, containing $\left(\mathrm{g} \mathrm{l}^{-1}\right): \mathrm{KNO}_{3}, 0 \cdot 25 ; \mathrm{NH}_{4} \mathrm{Cl}, 0 \cdot 25 ; \mathrm{KH}_{2} \mathrm{PO}_{4}$, $0 \cdot 13 ; \mathrm{Na}_{2} \mathrm{HPO}_{4} .12 \mathrm{H}_{2} \mathrm{O}, 0 \cdot 358 ; \mathrm{MgSO}_{4} .7 \mathrm{H}_{2} \mathrm{O}, 0 \cdot 4 ; \mathrm{CaCl}_{2}, 0 \cdot 1$; ferricEDTA, 0.00019; and $\mathrm{Na}_{2} \mathrm{MoO}_{4} \cdot 6 \mathrm{H}_{2} \mathrm{O}, 0 \cdot 00013$. To this medium was added $0.5 \mathrm{ml} \mathrm{l}^{-1}$ of a stock solution of trace elements, containing $\left(\mathrm{g} \mathrm{l}^{-1}\right)$ : $\mathrm{CuSO}_{4} .5 \mathrm{H}_{2} \mathrm{O}, 0 \cdot 2 ; \mathrm{FeSO}_{4} .7 \mathrm{H}_{2} \mathrm{O}, 0 \cdot 5 ; \mathrm{ZnSO}_{4} .7 \mathrm{H}_{2} \mathrm{O}, 0 \cdot 4$; $\mathrm{H}_{3} \mathrm{BO}_{3}, 0 \cdot 015 ; \mathrm{CoCl}_{2} \cdot 6 \mathrm{H}_{2} \mathrm{O}, 0 \cdot 05$; disodium EDTA, $0 \cdot 25 ; \mathrm{MnCl}_{2} .4 \mathrm{H}_{2} \mathrm{O}$, $0 \cdot 02$; and $\mathrm{NiCl}_{2} \cdot 6 \mathrm{H}_{2} \mathrm{O}, 0 \cdot 01$. The $\mathrm{pH}$ of the medium was adjusted to $6 \cdot 8$ with $\mathrm{NaOH}$. In addition, $2 \cdot 5 \mathrm{ml} \mathrm{l}^{-1}$ of a filter-sterilized vitamin stock solution $\left[\mathrm{mg}^{-1}\right.$ : thiamine hydrochloride, 10; nicotinic acid, 20; pyridoxamine, 10; $p$-aminobenzoic acid, 10; riboflavin, 20; biotin, 1 ; and cyanocobalamin (vitamin $\mathrm{B}_{12}$ ), 1] was added to media used for the enrichment, which was performed at $59^{\circ} \mathrm{C}$ in $50 \mathrm{ml}$ ANMS medium in $250 \mathrm{ml}$ conical flasks. The gas phase of the flasks was replaced by a methane/air mixture $(1: 1)$ every $3-4$ days. The cultures were shaken at 100 r.p.m. (Clim-O-Shaker).

Isolation of methanotrophs. The mineral composition of the growth medium was optimized, based on an analysis of the methane consumption activities. Rates of ${ }^{14} \mathrm{C}$-methane oxidation and assimilation by cells incubated in basal ANMS medium and in two- or fourfold-concentrated media, and also in ANMS medium containing various concentrations of trace elements, were estimated by using the method described previously (Sokolov \& Trotsenko, 1995). Since the rate of methane oxidation was higher at elevated concentrations of the trace elements (two- or fourfold) and both processes (methane oxidation and methane assimilation) were inhibited by $\mathrm{CaCl}_{2}$, the medium was modified slightly and then used for pure culture isolation. The modified $(\mathrm{M})$ medium contained $\left(\mathrm{g} \mathrm{l}^{-1}\right)$ : $\mathrm{NH}_{4} \mathrm{Cl}, 0 \cdot 5 ; \mathrm{KH}_{2} \mathrm{PO}_{4}, 0 \cdot 13 ; \mathrm{Na}_{2} \mathrm{HPO}_{4} .12 \mathrm{H}_{2} \mathrm{O}, 0 \cdot 358 ; \mathrm{MgSO}_{4} .7 \mathrm{H}_{2} \mathrm{O}$, $0.5 ; \mathrm{CaCl}_{2}, 0.02$; ferric-EDTA, $0 \cdot 0038 ; \mathrm{Na}_{2} \mathrm{MoO}_{4} \cdot 6 \mathrm{H}_{2} \mathrm{O}, 0 \cdot 00026$; and $1 \mathrm{ml} \mathrm{l}^{-1}$ of a stock solution of trace elements containing $\left(\mathrm{g} \mathrm{l}^{-1}\right)$ : $\mathrm{CuSO}_{4} .5 \mathrm{H}_{2} \mathrm{O}, 0 \cdot 2 ; \mathrm{FeSO}_{4} .7 \mathrm{H}_{2} \mathrm{O}, 0 \cdot 5 ; \mathrm{ZnSO}_{4} .7 \mathrm{H}_{2} \mathrm{O}, 0 \cdot 4$; $\mathrm{H}_{3} \mathrm{BO}_{3}, 0 \cdot 015 ; \mathrm{CoCl}_{2} \cdot 6 \mathrm{H}_{2} \mathrm{O}, 0 \cdot 05$; disodium EDTA, $0 \cdot 25 ; \mathrm{MnCl}_{2} .4 \mathrm{H}_{2} \mathrm{O}$, $0 \cdot 02$; and $\mathrm{NiCl}_{2} \cdot 6 \mathrm{H}_{2} \mathrm{O}, 0 \cdot 01$. M medium was not supplemented with vitamin solution.

After two or three passages of the enrichment in liquid ANMS and then in $\mathrm{M}$ medium, serial dilutions were spread onto plates containing a mixture of $80 \% \mathrm{M}$ medium and $20 \%$ autoclaved culture fluid from the initial enrichment, and $2.0 \%(\mathrm{w} / \mathrm{v})$ Bacto agar (Difco). The plates were incubated for $1-2$ weeks at $53{ }^{\circ} \mathrm{C}$ in anaerobic jars filled with a methane/air $(1: 1)$ gas mixture. Individual colonies were restreaked onto fresh plates and reincubated. The resulting single colonies were checked for purity by light microscopy and placed into liquid $\mathrm{M}$ medium. Pure cultures were routinely maintained at $53^{\circ} \mathrm{C}$ on solidified $\mathrm{M}$ medium. Absence of growth on various organic solid media and cell uniformity tested by light and electron microscopy were used as criteria for culture purity.

Electron microscopy. Ultrathin sections of exponentially grown cells and negatively stained preparations were prepared and examined using a JEOL JEM 100B electron microscope, as described previously (Khmelenina et al., 1999).

Utilizable carbon and nitrogen sources. The ability of the isolate to use various organic compounds as a carbon source was tested in liquid $\mathrm{M}$ medium supplemented with autoclaved or filter-sterilized substrates (methylamine, formate, formaldehyde, formamide, acetate, pyruvate, citrate, malate, succinate, D-glucose, D-xylose, D-arabinose, maltose, sucrose, mannitol, ethanol, glycerol and yeast extract) at a final concentration of $0.5 \mathrm{~g} \mathrm{l}^{-1}$. The ability of the isolate to grow on methanol was tested using a liquid mineral medium containing $0 \cdot 05-1 \%(\mathrm{v} / \mathrm{v})$ methanol. Nitrogen sources were tested by using agar medium in which $\mathrm{NH}_{4} \mathrm{Cl}$ was replaced by one of the following compounds at a final concentration of $0.05 \%$ (w/v): $\mathrm{KNO}_{3}$, $\mathrm{NaNO}_{2},\left(\mathrm{NH}_{4}\right)_{2} \mathrm{SO}_{4}$, methylamine, dimethylamine, urea, formamide, glycine, L-alanine, L-lysine, L-arginine, L-glutamate, L-glutamine, L-asparagine, L-lysine, L-aspartate, L-tryptophan, L-methionine, L-threonine, L-cysteine, L-histidine, Tris, disodium EDTA, Casamino acids and yeast extract.

Effect of pH, temperature and salinity on growth. The temperature range for growth was estimated by growing the isolate in liquid $\mathrm{M}$ medium at $26,30,37,54,57,59,62,65,67$ and $69^{\circ} \mathrm{C}$. The effect of $\mathrm{pH}$ was investigated at an optimum temperature of $57^{\circ} \mathrm{C}$, in $\mathrm{M}$ medium supplemented with $\mathrm{NaH}_{2} \mathrm{PO}_{4} / \mathrm{Na}_{2} \mathrm{HPO}_{4}$ buffer of various $\mathrm{pH}$ values $(4 \cdot 2-8 \cdot 5)$, at a final concentration of $0 \cdot 025 \mathrm{M}$. To test the salt-dependence of growth, $\mathrm{NaCl}$ was added to $\mathrm{M}$ medium at $0 \cdot 25,0 \cdot 5,1,2$ or $3 \%(\mathrm{w} / \mathrm{v}) ; 10 \mathrm{ml}$ of the culture grown at $\mathrm{pH} 6 \cdot 8$ was used for inoculation. Aliquots were taken at $12-18 \mathrm{~h}$ intervals and the optical density at $600 \mathrm{~nm}\left(\mathrm{OD}_{600}\right)$ was measured. The specific growth rate was calculated from increases in $\mathrm{OD}_{600}$ during the exponential growth phase. To test the copper-dependence of ${ }^{14} \mathrm{CH}_{4}$ assimilation and oxidation rates, the cells were suspended in ANMS medium containing $0 \cdot 4 \mu \mathrm{M} \mathrm{CuSO} 4.5 \mathrm{H}_{2} \mathrm{O}$, and additionally supplemented with $\mathrm{CuSO}_{4} \cdot 5 \mathrm{H}_{2} \mathrm{O}(0,0 \cdot 5,1,2$ and $4 \mu \mathrm{M})$. The cell suspensions were incubated at $57^{\circ} \mathrm{C}$ and the radioactivity incorporated into the biomass or carbon dioxide was measured as described below.

Antibiotic sensitivity. To test for antibiotic sensitivity, the cells were spread onto plates of solidified $\mathrm{M}$ medium with discs (Difco) containing the following antibiotics $\left(\mu \mathrm{g} \mathrm{ml}^{-1}\right)$ : neomycin, 30; kanamycin, 30; ampicillin, 10; erythromycin, 15; lincomycin, 2; gentamicin, 10; novobiocin, 30; nalidixic acid, 30; or streptomycin, 10. Growth under methane was assessed after 1-2 weeks.

Enzyme assays. To determine soluble methane monooxygenase (sMMO) activity, naphthalene oxidation by 1-week-old colonies 
grown on solid $\mathrm{M}$ medium without added copper was tested (Graham et al., 1992). Particulate methane monooxygenase (pMMO) activity was measured as ${ }^{14} \mathrm{CH}_{4}$ consumption by whole cells (Sokolov \& Trotsenko, 1995). For the preparation of cell-free extracts, exponentially grown cells were harvested by centrifugation at $6000 \mathrm{~g}$ for $30 \mathrm{~min}$, and washed once in $50 \mathrm{mM}$ Tris/HCl buffer $(\mathrm{pH} \mathrm{7.5)} \mathrm{con-}$ taining $5 \mathrm{mM} \mathrm{MgCl}_{2}$. The cells were resuspended in the same buffer. Cells $(0.5 \mathrm{~g}$ in $2 \mathrm{ml}$ buffer $)$ were sonicated three times for $30 \mathrm{~s}$ using an MSE sonifer $(150 \mathrm{~W}, 20 \mathrm{kHz})$, in ice-cooled cuvettes. Cell debris was precipitated by centrifugation at $15000 \mathrm{~g}$ for $30 \mathrm{~min}$. The supernatant was used for enzyme assays, which were performed as described previously (Kalyuzhnaya et al., 1999).

Cellular fatty acid profile and phospholipid analyses. For phospholipid analysis, exponentially grown cells at optimum temperature $\left(59^{\circ} \mathrm{C}\right)$ were harvested by centrifugation at $7000 \mathrm{~g}$ for $10 \mathrm{~min}$. Phospholipids were determined according to the method described previously (Govorukhina \& Trotsenko, 1989). Fatty acids and ubiquinones were analysed as described previously (Doronina et al., 2003).

DNA isolation and DNA G+C content determination. DNA was isolated as described previously (Kalyuzhnaya et al., 1999). DNA $\mathrm{G}+\mathrm{C}$ content was determined by using the thermal denaturation method (Sambrook et al., 1989).

Comparative sequence analysis. For PCR of the $16 \mathrm{~S}$ rRNA gene, the universal bacterial primers 27f and 1492r (Giovannoni, 1991) were used. Amplification of a partial fragment of the $p m o A$ gene (encoding the $27 \mathrm{kDa}$ peptide of pMMO) was done using primers A189 and mb661r (Bourne et al., 2001). Amplification of partial fragments of the mmoX gene (encoding the $\alpha$-subunit of sMMO) was performed using primers according to PCR programmes described by Murrell et al. (1998). Amplification of partial fragments of the nifH (encoding the iron protein of the nitrogenase) and $c b b L$ (encoding the large subunit of ribulose-1,5-bisphosphate carboxylase/ oxygenase) genes was performed as described by Dedysh et al. (2004) and Baxter et al. (2002), respectively. PCR was performed using a Hybaid Thermocycler, with a mixture containing TaqPol buffer (USB), $0 \cdot 2 \mu \mathrm{g}$ chromosomal DNA, $0.5 \mu \mathrm{M}$ oligonucleotide primers, $0.5 \mathrm{mM}$ each $\mathrm{dNTP}, 2.5 \mathrm{mM} \mathrm{MgCl}_{2}$ and $2 \mathrm{U}$ Taq polymerase. After denaturation at $95^{\circ} \mathrm{C}$ for $2 \mathrm{~min}$, the reaction mixture was subjected to 25 thermal cycles: $94{ }^{\circ} \mathrm{C}, 50 \mathrm{~s} ; 50 \mathrm{~s}$ at annealing temperature $\left(56^{\circ} \mathrm{C}\right.$ for $p m o A$ gene-specific and $60^{\circ} \mathrm{C}$ for $16 \mathrm{~S}$ rRNA gene-specific primers); $72^{\circ} \mathrm{C}, 50 \mathrm{~s}$. At the final stage, the reaction mixture was incubated for $5 \mathrm{~min}$ at $72{ }^{\circ} \mathrm{C}$. The size of the reaction products was checked on $1 \%(\mathrm{w} / \mathrm{v})$ agarose gels. For sequencing, the reaction products were separated by electrophoresis in $1 \%$ lowmelting point agarose (Gibco), and then the bands of corresponding size were excised and purified by using the agarase (Fermentas) digestion procedure, according to the manufacturer's protocol. The PCR products were sequenced by using a FemtoMol kit (Promega). Inferred polypeptide sequences of PmoA and 16S rRNA gene sequences were aligned manually with sequences retrieved from the GenBank database, using the CLUSTAL package of multiple alignment programs (Higgins \& Sharp, 1988). Dendrograms were constructed using the TREECON programs package (version 1.3b) (Van de Peer \& De Wachter, 1994).

\section{RESULTS AND DISCUSSION}

\section{Isolation of strain $\mathbf{M Y H T}^{\mathbf{T}}$}

Vitamins were required at the initial step of the methanotroph enrichment. Also, the enrichment grew better in liquid or on solidified ANMS media when culture fluid from the initial enrichment was added, implying possible growth factor limitation. However, various colony types were obtained on solidified ANMS medium containing vitamins, and only heterotrophic contaminants remained after several transfers. Therefore, vitamins supporting the growth of both the methanotrophs and the heterotrophic satellites were excluded from the growth medium. Of the antibiotics tested, only erythromycin and nalidixic acid did not suppress growth of the methanotrophs, but slightly inhibited growth of heterotrophic contaminants. Thus, addition of these antibiotics to plates and improvement of the mineral composition of the medium favoured the isolation of a pure methanotrophic culture after several transfers.

\section{Cultural and morphological characteristics}

Small (1-2 mm in diameter), white, semi-transparent colonies with an entire edge and smooth surface were observed on agar plates after incubation at $53^{\circ} \mathrm{C}$ for $1-2$ weeks. Older colonies ( 1 month) became light brown and more rigid. The colonies grew faster and were relatively large $(3 \mathrm{~mm}$ in diameter) when vitamins were added to the growth medium. As revealed by light microscopy, the cells grown in liquid culture in either exponential or stationary phase were mostly represented by coccoids of $0 \cdot 6-0 \cdot 8 \mu \mathrm{m}$ in diameter (Fig. 1a). In contrast, the majority of cells grown on solid medium appeared as short rods, slightly varying in size $(0 \cdot 6-0 \cdot 8 \times 1 \cdot 0-1 \cdot 2 \mu \mathrm{m})$. The cells were non-motile, and multiplied by normal cell division. Electron microscopy analysis of ultrathin sections of cells showed a typical Gram-negative structure of the cell wall, and the presence of type I intracytoplasmic membrane (ICM) arranged as stacks of vesicular disks (Fig. 1b) that completely filled the cytoplasmic space. Glycogen inclusions and poly- $\beta$ hydroxybutyrate granules usually present in mesophilic methanotrophs were not observed. Also, the cells formed regularly arranged surface layers with $p 2$ symmetry (Fig. 1c).

\section{Physiological characteristics}

Strain MYHT $^{\mathrm{T}}$ did not grow on the multicarbon substrates tested and used only methane and methanol as a carbon and energy source. Nitrate, ammonia, urea, tryptophan, lysine, glutamate, formamide and Tris were utilized as a nitrogen source. No growth was observed on nitrogen-free medium and the nifH gene was not detected with PCR analysis.

Maximal growth rate occurred at $57-59^{\circ} \mathrm{C}$. Strain $\mathrm{MYHT}^{\mathrm{T}}$ was able to grow at 37 and $67^{\circ} \mathrm{C}$. Interestingly, the cells oxidized and assimilated methane even at $75^{\circ} \mathrm{C}$ (see Supplementary Figure in IJSEM Online). The strain grew best at $57^{\circ} \mathrm{C}$ in the presence of $0.5-1 \% \mathrm{NaCl}$ (specific growth rate $0 \cdot 1 \mathrm{~h}^{-1}$ and generation time $7 \mathrm{~h}$ ). The optimum $\mathrm{NaCl}$ concentration for growth at $65^{\circ} \mathrm{C}$ was $0.5 \%(\mathrm{w} / \mathrm{v})$. The isolate was capable of growth in up to $3 \% \mathrm{NaCl}$ at $57^{\circ} \mathrm{C}$, but only in up to $1 \% \mathrm{NaCl}$ at $65^{\circ} \mathrm{C}$. The $\mathrm{pH}$ range for growth was $6 \cdot 5-7 \cdot 5$. Cells oxidized methane most actively in the presence of $0 \cdot 9-1 \cdot 4 \mu \mathrm{M} \mathrm{CuSO}_{4}$. Higher copper 

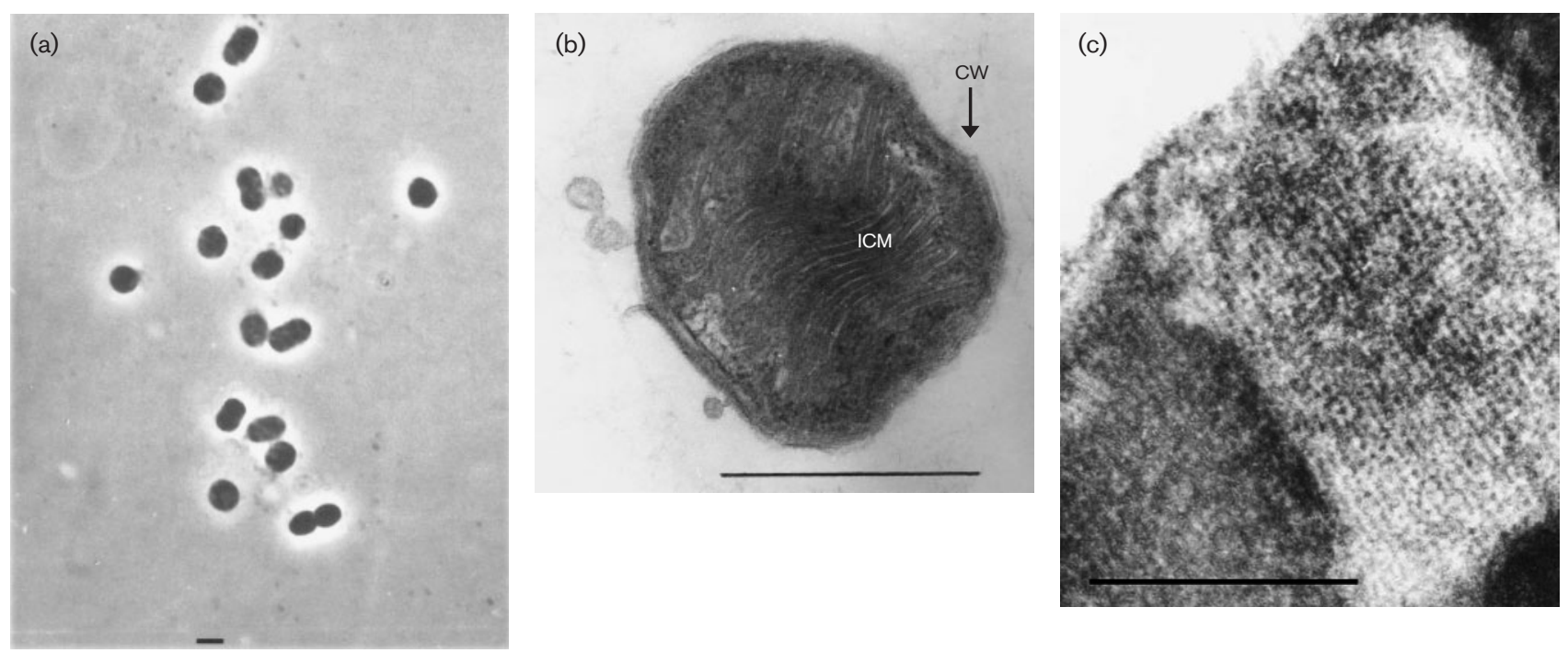

Fig. 1. Cell morphology of strain $\mathrm{MYHT}^{\top}$. (a) Phase-contrast micrograph. (b) Ultrathin section of cell showing cell wall structure (CW) and the intracytoplasmic membrane (ICM) arrangement. (c) Highly magnified, negative-contrast image showing the surface layer with linear (p2) symmetry. Bars, $1 \mu \mathrm{m}(\mathrm{a}), 0.5 \mu \mathrm{m}(\mathrm{b})$ and $0.1 \mu \mathrm{m}$ (c).

concentrations (up to $2 \cdot 4 \mu \mathrm{M}$ ) did not influence methane consumption.

\section{Phospholipid fatty acid (PLFA) profiles}

As can be seen from Table 1, strain $\mathrm{MYHT}^{\mathrm{T}}$ contained specific fatty acids, consisting mainly of $\mathrm{C}_{16: 0}(37 \cdot 24 \%)$ and $\mathrm{C}_{18: 1} \omega 9 c(35 \cdot 16 \%)$. The major polar lipids were phosphatidylethanolamine and phosphatidylglycerol. The major ubiquinone was Q-8.

\section{Metabolic pattern}

Cells grown under both copper-containing and copperdepleted conditions did not oxidize naphthalene, suggesting the absence of sMMO. Also, the mmoX gene was not detected by PCR using the respective primer set that is universal for the known mmoX genes of methanotrophs. Hence, pMMO activity appeared to be located in the ICM. Activities of the following enzymes involved in the sequential linear oxidation of $\mathrm{CH}_{4}$ to $\mathrm{CO}_{2}$ were found in cell-free extracts: methanol dehydrogenase, which is active with phenazine methosulphate as an artificial electron acceptor, and $\mathrm{NAD}^{+}$-dependent formate and formaldehyde dehydrogenases. Hexulosephosphate synthase activity was detected (Table 2), suggesting that strain $\mathrm{MYHT}^{\mathrm{T}}$ assimilates methane carbon at the formaldehyde level via the ribulose monophosphate (RuMP) cycle. Neither hydroxypyruvate reductase (NADH) nor serine-glyoxylate aminotransferase activities were found, thus excluding the operation of the serine pathway. Also, no activity of the key enzyme of the Calvin cycle, ribulose-1,5-bisphosphate carboxylase/oxygenase, was found. The appropriate $c b b L$ gene was not revealed by PCR. The complete tricarboxylic acid cycle does not operate in this organism because of the absence of $\alpha$-ketoglutarate dehydrogenase. Like many other methanotrophs, in strain $\mathrm{MYHT}^{\mathrm{T}}$ the pyrophosphatedependent, but not the ATP-dependent, 6-phosphofructokinase was operative. Also, two possibilities for the cleavage of hexosephosphates exist, via fructose-1,6-bisphosphate aldolase and 2-keto-3-deoxy-6-phosphogluconate aldolase. The presence of glutamine synthetase and glutamate synthase activities indicated the involvement of the glutamate cycle in ammonia assimilation by strain $\mathrm{MYHT}^{\mathrm{T}}$.

\section{Genomic characteristics}

The G + C DNA content of $62 \cdot 5 \mathrm{~mol} \%$ for strain $\mathrm{MYHT}^{\mathrm{T}}$ is close to that found for type II and type X methanotrophs. The 16S rRNA gene database search showed that strain MYHT $^{\mathrm{T}}$ belongs to the class 'Gammaproteobacteria'. It is closely related to the thermophilic methanotroph 'Methylothermus' HB ( $91 \%$ sequence identity, based on the comparison of 1442 available bases) and the novel halophilic methanotroph Methylohalobius crimeensis $10 \mathrm{Ki}^{\mathrm{T}}(90 \%)$. The other closest neighbours were the moderately thermophilic methanotrophs Methylococcus thermophilus ACM $3585^{\mathrm{T}}$ and Methylocaldum szegediense $\mathrm{OR} 2^{\mathrm{T}}$, and the thermotolerant Methylococcus capsulatus Bath (about 85-86\% $16 \mathrm{~S}$ rRNA gene sequence identity). The phylogenetic position of strain $\mathrm{MYHT}^{\mathrm{T}}$ within methanotrophs belonging to the class 'Gammaproteobacteria' is shown in Fig. 2.

Phylogenetic analysis based on partial pmoA gene sequences confirmed the clustering of strain $\mathrm{MYHT}^{\mathrm{T}}$ with 'Methylothermus' strain HB ( $90 \%$ nucleotide sequence identity and $98 \%$ derived amino acid sequence identity) and Methylohalobius crimeensis $10 \mathrm{Ki}^{\mathrm{T}}$ ( 83 and $92 \%$, respectively) (Fig. 3). In contrast, the partial pmoA gene sequence of 
Table 1. Cellular fatty acid profiles of strain $\mathrm{MYHT}^{\top}$ and the most closely related known methanotrophs

Strains: 1, Methylococcus capsulatus Bath (data from Bowman et al., 1993); 2, Methylococcus thermophilus ACM $3585^{\mathrm{T}}$ (Bowman et al., 1993); 3, Methylocaldum sp. O-12 (Eshinimaev et al., 2004); 4, Methylohalobius crimeensis $10 \mathrm{Ki}^{\mathrm{T}}$ (Heyer et al., 2005); 5, strain $\mathrm{MYHT}^{\mathrm{T}}$ (this study). Values are given as a percentage of total fatty acids.

\begin{tabular}{|c|c|c|c|c|c|}
\hline Fatty acid & 1 & 2 & 3 & 4 & 5 \\
\hline $\mathrm{C}_{14: 0}$ & $0 \cdot 8-0 \cdot 62$ & $1 \cdot 5-1 \cdot 9$ & $1 \cdot 97$ & $2 \cdot 45$ & $1 \cdot 24$ \\
\hline $\mathrm{C}_{14: 0} 2-\mathrm{OH}$ & & & & & $0 \cdot 33$ \\
\hline $\mathrm{C}_{15: 0}$ & $0-1 \cdot 7$ & $0-12 \cdot 7$ & $3 \cdot 51$ & $0 \cdot 48$ & $2 \cdot 07$ \\
\hline $\mathrm{C}_{15: 0} 2-\mathrm{OH}$ & & & & & $0 \cdot 17$ \\
\hline $\mathrm{C}_{16: 0}$ & $22 \cdot 5-22 \cdot 9$ & $39 \cdot 7-47 \cdot 0$ & $63 \cdot 67$ & $23 \cdot 02$ & $37 \cdot 24$ \\
\hline $\mathrm{C}_{16: 1}$ & $12 \cdot 4-55$ & $17 \cdot 2-56$ & $11 \cdot 90$ & & \\
\hline $\mathrm{C}_{16: 1} \omega 7 c$ & & & & $19 \cdot 60$ & $3 \cdot 46$ \\
\hline $\mathrm{C}_{16: 0} 2-\mathrm{OH}$ & & & & 0.93 & $8 \cdot 41$ \\
\hline $\mathrm{C}_{16: 0} 3-\mathrm{OH}$ & & & $0 \cdot 64$ & & \\
\hline $9-\mathrm{O}-\mathrm{Me}-\mathrm{C}_{16: 0}$ & & & $4 \cdot 62$ & & \\
\hline $\mathrm{C}_{17: 0}$ & 0 to traces & $0-1 \cdot 4$ & $0 \cdot 68$ & $0 \cdot 29$ & $2 \cdot 52$ \\
\hline $\mathrm{C}_{17: 1}$ & & & & & $0 \cdot 19$ \\
\hline $\mathrm{i}-\mathrm{C}_{17: 1}$ & & & $0 \cdot 34$ & & \\
\hline $\mathrm{C}_{17: 1} \omega 6$ & & & $0 \cdot 43$ & & \\
\hline $\mathrm{C}_{17: 1} \omega 8$ & 0 to traces & $0-0 \cdot 4$ & $0 \cdot 26$ & & \\
\hline $\mathrm{C}_{17} \mathrm{cyc}$ & $0-14 \cdot 0$ & $0-15 \cdot 1$ & $8 \cdot 99$ & $0 \cdot 67$ & $4 \cdot 71$ \\
\hline $9-\mathrm{O}-\mathrm{Me}-\mathrm{C}_{17: 0}$ & & & $0 \cdot 60$ & & \\
\hline $11-\mathrm{O}-\mathrm{Me}-\mathrm{C}_{17: 0}$ & & & $0 \cdot 60$ & & \\
\hline $\mathrm{C}_{18: 0}$ & $0-2 \cdot 8$ & $0 \cdot 1-0 \cdot 7$ & $0 \cdot 26$ & $0 \cdot 47$ & $1 \cdot 74$ \\
\hline $\mathrm{C}_{18: 1}$ & $0-9 \cdot 4$ & Traces to $3 \cdot 4$ & $0 \cdot 17$ & & \\
\hline $\mathrm{C}_{18: 1} \omega 7 c$ & & & & $51 \cdot 87$ & $0 \cdot 35$ \\
\hline $\mathrm{C}_{18: 1} \omega 9 c$ & & & & & $35 \cdot 16$ \\
\hline $\mathrm{C}_{19: 0 \mathrm{cyc}}$ & $0 \cdot 6-1 \cdot 8$ & $0-2 \cdot 9$ & & & \\
\hline $\mathrm{C}_{19: 1} \mathrm{cyc}$ & & & $1 \cdot 37$ & & $2 \cdot 41$ \\
\hline
\end{tabular}

strain $\mathrm{MYHT}^{\mathrm{T}}$ exhibited no more than $77 \%$ identity to the corresponding gene fragments (460 bp) of Methylocaldum szegediense OR2 ${ }^{\mathrm{T}}$, Methylocaldum gracile $\mathrm{VKM}-14 \mathrm{~L}^{\mathrm{T}}$ and Methylococcus capsulatus Bath.

Given all the characteristic features of $\mathrm{MYHT}^{\mathrm{T}}$, we believe that this novel isolate should be classified as a type I thermophilic methanotroph. So far, information on true thermophilic methanotrophs is limited, with only a brief and non-formal taxonomic description of 'Methylothermus' strain HB. Because the physiological, biochemical and molecular properties of 'Methylothermus' strain $\mathrm{HB}$ were poorly investigated, a comparison of strain $\mathrm{HB}$ with strain MYHT $^{\mathrm{T}}$ is rather difficult. The lack of information was probably caused by the weak growth of 'Methylothermus' strain $\mathrm{HB}$, which did not exceed $\mathrm{OD}_{540} 0 \cdot 15$, and therefore sufficient biomass could not be obtained (Bodrossy et al., 1999). We have improved the growth of our isolate by optimization of the medium composition, by studying ${ }^{14} \mathrm{C}$-methane consumption and oxidation by cells. In contrast to 'Methylothermus' strain $\mathrm{HB}$, isolate $\mathrm{MYHT}^{\mathrm{T}}$
Table 2. Enzyme activities in cell extracts of strain $\mathrm{MYHT}^{\top}$ Activities are given as $\mathrm{nmol} \mathrm{min}^{-1}(\mathrm{mg} \text { protein })^{-1}$. Abbreviation: PMS, phenazine methosulphate. There was no activity with any of the following enzymes and cofactors: formaldehyde dehydrogenase (PMS), ribulose-1,5-bisphosphate carboxylase/oxygenase, serineglyoxylate transaminase, hydroxypyruvate reductase (NADH), $\alpha$ ketoglutarate dehydrogenase (NAD), glutamate synthase (NADPH) and 6-phosphofructokinase (ATP).

\begin{tabular}{|lcc|}
\hline Enzyme & Cofactor & Activity \\
\hline Particulate methane monooxygenase $^{*}$ & - & $5 \cdot 0$ \\
Methanol dehydrogenase & $\mathrm{PMS}$ & 28 \\
Formaldehyde dehydrogenase & $\mathrm{NAD}$ & $0 \cdot 8$ \\
Formate dehydrogenase & $\mathrm{PMS}$ & $8 \cdot 6$ \\
& $\mathrm{NAD}$ & $39 \cdot 3$ \\
Hexulosephosphate synthase & - & 97 \\
6-Phosphofructokinase & $\mathrm{PP}_{\mathrm{i}}$ & $2 \cdot 6$ \\
Fructose-1,6-bisphosphate aldolase & - & 12 \\
2-Keto-3-deoxy-6-phosphogluconate aldolase & - & $1 \cdot 7$ \\
Phosphoenolpyruvate carboxylase & - & $0 \cdot 5$ \\
Pyruvate carboxylase & - & $1 \cdot 9$ \\
Glutamate dehydrogenase & $\mathrm{NADPH}$ & 1.6 \\
Glutamine synthetase & $\mathrm{ATP}$ & $3 \cdot 8$ \\
Glutamate synthase & $\mathrm{NADH}$ & 4 \\
\hline
\end{tabular}

${ }^{\star}$ Measured as ${ }^{14} \mathrm{CH}_{4}$ consumption by whole cells.

was able to grow up to an $\mathrm{OD}_{600}$ value of $1 \cdot 0$, with a rather high growth rate $\left(\mu=0 \cdot 1 \mathrm{~h}^{-1}\right)$. Although the addition of vitamins stimulated the growth of both methanotrophs, these factors were excluded from the medium used for cultivation of strain $\mathrm{MYHT}^{\mathrm{T}}$, to prevent its possible contamination and subsequent loss of the culture.

In principle, the colony and cell morphologies of strain $\mathrm{MYHT}^{\mathrm{T}}$ were similar to those of 'Methylothermus' strain HB (Bodrossy et al., 1999). Also, both organisms required the same level of $\mathrm{CuSO}_{4}$ for growth and lacked sMMO. However, the upper temperature limit for growth $\left(72^{\circ} \mathrm{C}\right)$ and optimum values $\left(62-65^{\circ} \mathrm{C}\right)$ were somewhat higher for 'Methylothermus' HB. Furthermore, the 16S rRNA gene similarity between strain $\mathrm{MYHT}^{\mathrm{T}}$ and 'Methylothermus' $\mathrm{HB}$ was low, indicating the affiliation of these strains at least to different species.

The metabolic pattern of strain $\mathrm{MYHT}^{\mathrm{T}}$ was quite different from those of the extant thermophilic/tolerant type $\mathrm{X}$ methanotrophs belonging to the genera Methylococcus and Methylocaldum, but was similar to that of the extremely halophilic Methylohalobius crimeensis (Table 3). Obviously, strain MYHT $^{\mathrm{T}}$ uses only the RuMP cycle for carbon assimilation, whereas type $\mathrm{X}$ methanotrophs assimilate formaldehyde via both the RuMP and serine pathways, and are also able to grow autotrophically. These important differentiating properties allowed us to consider strain $\mathrm{MYHT}^{\mathrm{T}}$ to be a type I methanotroph (Table 3). 
$0 \cdot 1$

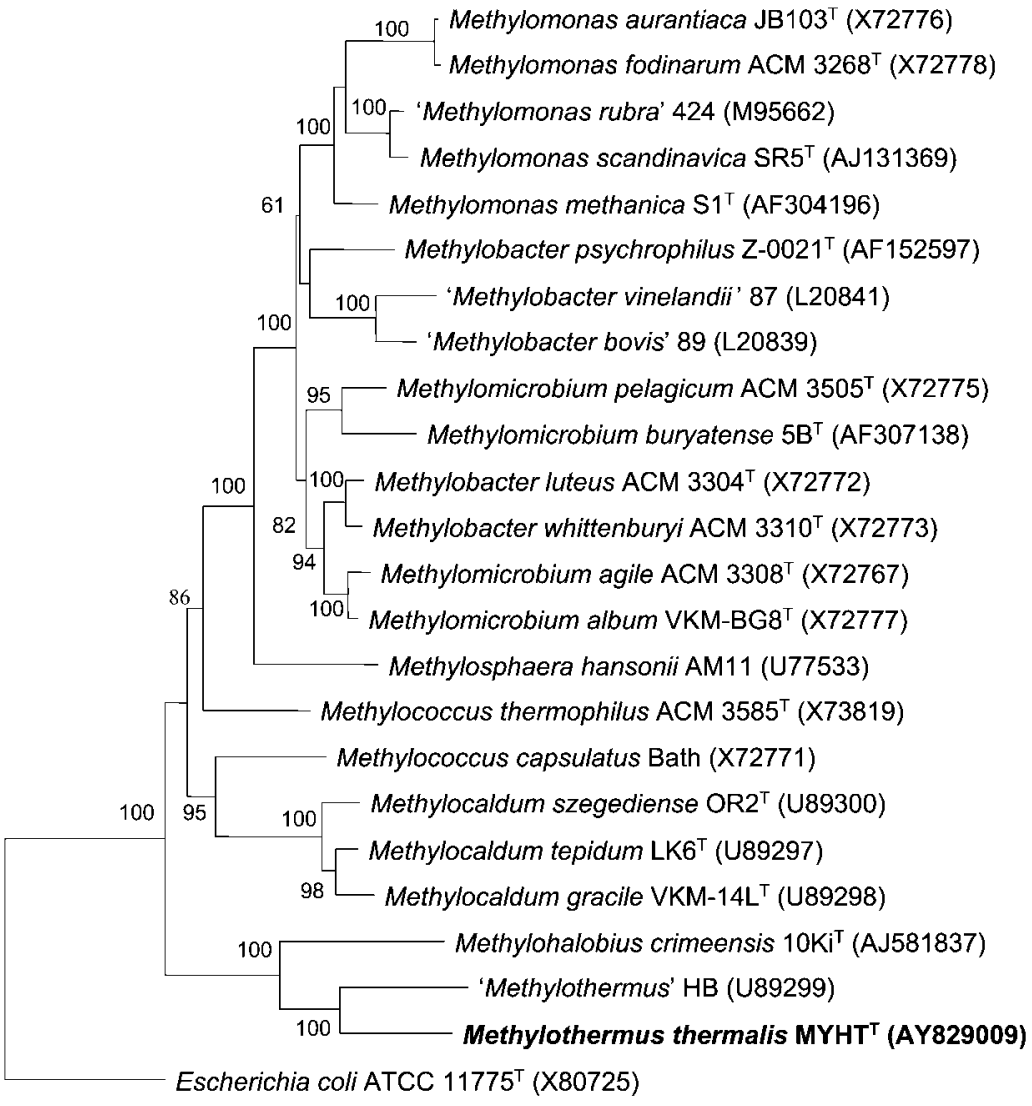

Fig. 2. Phylogenetic tree showing the relationship of the 16S rRNA gene sequence of strain $\mathrm{MYHT}^{\top}$ to those of some methanotrophs in the class 'Gammaproteobacteria'. The sequences were aligned using the CLUSTAL program; $1200 \mathrm{bp}$ were used for the tree construction with the TREECON program (version 1.3b) using the neighbourjoining algorithm. Bootstrap values less than $50 \%$ are not shown. The tree was rooted using Escherichia coli. Bar, 0.1 substitutions per base position. GenBank accession numbers are given in parentheses.
The specificity of the cellular fatty acid composition, consisting primarily of $\mathrm{C}_{16: 0}$ and $\mathrm{C}_{18: 1} \omega 9 \mathrm{c}$ in equal proportions, clearly distinguishes strain $\mathrm{MYHT}^{\mathrm{T}}$ from the other extant methanotrophs. Usually, $\mathrm{C}_{16}$ fatty acids prevail in PLFA profiles of type I and type X methanotrophs, whereas
$\mathrm{C}_{18}$ fatty acids occur in very small amounts. In contrast, $\mathrm{C}_{18}$ fatty acids are predominant in type II methanotrophs. Only the newly isolated halophilic methanotroph Methylohalobius crimeensis belonging to the type I methanotrophs had a large proportion $(51 \cdot 87 \%)$ of $\mathrm{C}_{18: 1} \omega 7$ c (Heyer et al., 2005).

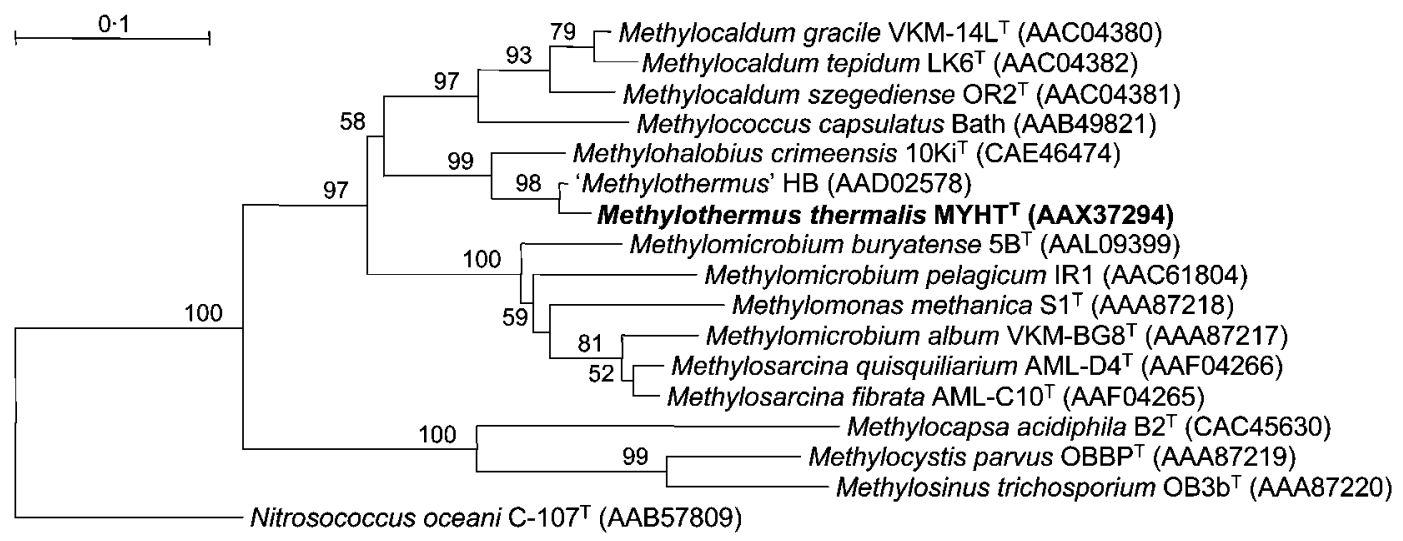

Fig. 3. Phylogenetic analysis of partial amino acid sequences encoded by the $p m o A$ gene from some methanotrophs and the novel isolate $\mathrm{MYHT}^{\top}$. The partial AmoA protein sequence of the ammonia-oxidizing bacterium Nitrosococcus oceani served as an outgroup. The tree was constructed with the TREECON program (version 1.3b) using the neighbour-joining algorithm. Bootstrap analysis from 100 replicates is shown (values less than $50 \%$ are not shown). Bar, $0 \cdot 1$ substitutions per amino acid position. GenBank accession numbers are given in parentheses. 
Table 3. Major differentiating characteristics of the genera of thermotolerant and thermophilic methanotrophs

Genera: 1, Methylococcus (data from Bowman et al., 1993); 2, Methylocaldum (Bodrossy et al., 1997, 1999; Eshinimaev et al., 2004); 3, Methylohalobius (Heyer et al., 2005); 4, Methylothermus (this study, strain MYHT $^{\mathrm{T}}$ ). Abbreviations: ND, not determined; RuBP, ribulose bisphosphate.

\begin{tabular}{|c|c|c|c|c|}
\hline Characteristic & 1 & 2 & 3 & 4 \\
\hline Motility & - & - & + & - \\
\hline ICM arrangement & type I & type I & type I & type I \\
\hline \multicolumn{5}{|l|}{ Growth parameters ${ }^{*}$ : } \\
\hline Temperature $\left({ }^{\circ} \mathrm{C}\right)$ & $20-55(45)$ & $30-61(55)$ & $15-42(30)$ & $37-67(57-59)$ \\
\hline Salinity $(\% \mathrm{NaCl})$ & ND & $0-2(0 \cdot 5)$ & $1 \cdot 5-15(6-9)$ & $0-3(0 \cdot 5-1)$ \\
\hline $\mathrm{CH}_{4}$ oxidation & sMMO/pMMO & pMMO & pMMO & pMMO \\
\hline $\mathrm{C}_{1}$ assimilation pathway & RuMP/RuBP & RuMP/RuBP & RuMP & RuMP \\
\hline$c b b L$ gene & + & + & - & - \\
\hline nifH gene & + & + & - & - \\
\hline
\end{tabular}

*Optimum values are given in parentheses.

Analysis of the 16S rRNA and pmoA genes clearly showed that strain $\mathrm{MYHT}^{\mathrm{T}}$, together with 'Methylothermus' strain $\mathrm{HB}$ and Methylohalobius crimeensis, represent a deepbranching group of extremophilic methanotrophs, which might indicate their common origin and consequent divergence. Therefore, strain MYHT ${ }^{\mathrm{T}}$ appears to be more closely related to the type I (mesophilic, halophilic methanotroph Methylohalobius) than to the type X (thermophilic/tolerant Methylococcus and Methylocaldum) methanotrophs.

Because the published data on the properties of 'Methylothermus' strain $\mathrm{HB}$ are not sufficient for a comprehensive comparison with those of strain $\mathrm{MYHT}^{\mathrm{T}}$, and also because strain $\mathrm{HB}$ is not available, we propose that strain $\mathrm{MYHT}^{\mathrm{T}}$ represents a new genus, Methylothermus gen. nov. Based on the phenotypic and genotypic properties, and phylogeny, we propose that isolate $\mathrm{MYHT}^{\mathrm{T}}$ should be classified as representing the type species of the genus Methylothermus, with the name Methylothermus thermalis sp. nov.

\section{Description of Methylothermus gen. nov.}

Methylothermus (Me.thy'lo.ther'mus. N.L. n. methyl the methyl group; N.L. masc. subst. from Gr. adj. thermos hot; Methylothermus methyl-using thermotolerant organism).

Cells are Gram-negative, non-motile coccoids, of $0 \cdot 6-0 \cdot 8 \mu \mathrm{m}$ in diameter. Reproduce by binary division. Exospores, Azotobacter-type cysts or lipid cysts are not formed. Possess pMMO and type I ICM as stacks of membrane vesicles. Do not possess sMMO. Moderate thermophiles growing at $37-67^{\circ} \mathrm{C}$ (optimum $57-59^{\circ} \mathrm{C}$ ). Obligate methanotrophs utilizing methane or methanol via the RuMP pathway.
Tricarboxylic acid cycle is deficient in $\alpha$-ketoglutarate dehydrogenase. Major PLFAs are $\mathrm{C}_{16: 0}$ and $\mathrm{C}_{18: 1} \omega 9 c$. Major phospholipids are phosphatidylethanolamine and phosphatidylglycerol. Phylogenetically belong to the class 'Gammaproteobacteria' (type I methanotrophs). Habitats are hot springs. The type species is Methylothermus thermalis.

\section{Description of Methylothermus thermalis sp. nov.}

Methylothermus thermalis (ther'mal.is. N.L. masc. adj. thermalis pertaining to a hot spring).

Description is as for the genus with the following amendments. Grows on nitrate, ammonia, urea, tryptophan, lysine, glutamine, formamide and Tris as a nitrogen source. Is not able to fix atmospheric nitrogen. Prefers media containing $0 \cdot 5-1 \% \mathrm{NaCl}$ and is capable of growth in $3 \% \mathrm{NaCl}$. Neutrophile, growing at $\mathrm{pH} 6 \cdot 5-7 \cdot 5$. DNA $\mathrm{G}+\mathrm{C}$ content is $62.5 \mathrm{~mol} \%$. The type strain is $\mathrm{MYHT}^{\mathrm{T}}$ ( =VKM B-2345 $=$ IPOD FERM P-19714 ${ }^{\mathrm{T}}$ ), which was isolated from a hot spring located in Hyogo, Japan.

\section{ACKNOWLEDGEMENTS}

The authors wish to thank Dr N. E. Suzina for skilful microscopic studies. Special thanks are due to Professors C. J. Murrell (Warwick University, Coventry, UK) and K. L. Kovács (Szeged University, Hungary) and the anonymous reviewers for valuable suggestions and comments. This work was supported in part by RFBR grant 05-0449515-a. 


\section{REFERENCES}

Baxter, N. J., Hirt, R. P., Bodrossy, L., Kovacs, K. L., Embley, T. M., Prosser, J. I. \& Murrell, J. C. (2002). The ribulose-1,5-bisphosphate carboxylase/oxygenase gene cluster of Methylococcus capsulatus (Bath). Arch Microbiol 177, 279-289.

Bodrossy, L., Murrell, J. C., Dalton, H., Kalman, M., Puskas, L. G. \& Kovacs, K. L. (1995). Heat-tolerant methanotrophic bacteria from the hot-water effluent of a natural-gas field. Appl Environ Microbiol 61, 3549-3555.

Bodrossy, L., Holmes, E. M., Holmes, A. J., Kovacs, K. L. \& Murrell, J. C. (1997). Analysis of $16 \mathrm{~S}$ rRNA and methane monooxygenase gene sequences reveals a novel group of thermotolerant and thermophilic methanotrophs, Methylocaldum gen. nov. Arch Microbiol 168, 493-503.

Bodrossy, L., Kovács, K. L., McDonald, I. R. \& Murrell, J. C. (1999). A novel thermophilic methane-oxidizing $\gamma$-Proteobacterium. FEMS Microbiol Lett 170, 335-341.

Bourne, D. G., McDonald, I. R. \& Murrell, J. C. (2001). Comparison of pmoA PCR primer sets as tools for investigating methanotroph diversity in three Danish soils. Appl Environ Microbiol 67, 3802-3809.

Bowman, J. P., Sly, L. I., Nichols, P. D. \& Hayward, A. C. (1993). Revised taxonomy of the methanotrophs: description of Methylobacter gen. nov., emendation of Methylococcus, validation of Methylosinus and Methylocystis species, and a proposal that the family Methylococcaceae includes only the group I methanotrophs. Int J Syst Bacteriol 43, 735-753.

Dedysh, S. N., Ricke, P. \& Liesack, W. (2004). NifH and NifD phylogenies: an evolutionary basis for understanding nitrogen fixation capabilities of methanotrophic bacteria. Microbiology 150, $1301-1313$

Doronina, N. V., Darmaeva, T. D. \& Trotsenko, Y. A. (2003). Methylophaga alcalica sp. nov., a novel alkaliphilic and moderately halophilic, obligately methylotrophic bacterium from an East Mongolian saline soda lake. Int J Syst Evol Microbiol 53, 223-229.

Eshinimaev, B. Ts., Medvedkova, K. A., Khmelenina, V. N., Suzina, N. E., Osipov, G. A., Lysenko, A. M. \& Trotsenko, Y. A. (2004). New thermophilic methanotrophs of the genus Methylocaldum. Mikrobiologiia 73, 530-539 (in Russian).

Foster, J. W. \& Davis, R. H. (1966). A methane-dependent coccus, with notes on classification and nomenclature of obligate, methaneutilizing bacteria. J Bacteriol 91, 1924-1931.

Giovannoni, S. J. (1991). The polymerase chain reaction. In Nucleic Acid Techniques in Bacterial Systematics, pp. 177-203. Edited by E. Stackebrandt \& M. Goodfellow. New York: Wiley.

Govorukhina, N. I. \& Trotsenko, Y. A. (1989). Phospholipid composition of methylotrophic bacteria. Microbiology (English translation of Mikrobiologiia) 58, 318-323.
Graham, D. W., Korich, D. G., LeBlanc, R. P., Sinclair, N. P. \& Arnold, R. G. (1992). Applications of a colorimetric plate assay for soluble methane monooxygenase activity. Appl Environ Microbiol 58, 2231-2236.

Hanson, R. S. \& Hanson, T. E. (1996). Methanotrophic bacteria. Microbiol Rev 60, 439-471.

Heyer, J., Berger, U., Hardt, M. \& Dunfield, P. F. (2005). Methylohalobius crimeensis gen. nov., sp. nov., a moderately halophilic, methanotrophic bacterium isolated from hypersaline lakes of Crimea. Int J Syst Evol Microbiol 55, 1817-1826.

Higgins, D. G. \& Sharp, P. M. (1988). CLUSTAL: a package for performing multiple sequence alignment on a microcomputer. Gene 73, 237-244.

Kalyuzhnaya, M. G., Khmelenina, V. N., Kotelnikova, S. Holmquist, L., Pedersen, K. \& Trotsenko, Y. A. (1999). Methylomonas scandinavica sp. nov., a new methanotrophic psychrotrophic bacterium isolated from deep igneous rock ground water of Sweden. Syst Appl Microbiol 22, 565-572.

Khmelenina, V. N., Kalyuzhnaya, M. G., Sakharovsky, V. G., Suzina, N. E., Trotsenko, Y. A. \& Gottschalk, G. (1999). Osmoadaptation in halophilic and alkaliphilic methanotrophs. Arch Microbiol 172, 321-329.

Malashenko, Y. R. (1976). Isolation and characterization of new species (thermophilic and thermotolerant ones) of methane-utilizers. In Microbial Growth on C1 Compounds, pp. 293-300. Edited by H.G. Schlegel, G. Gottshalk \& N. Pfenning. Gottingen: E. Goltze KG.

Malashenko, Y. R., Romanovskaya, V. A., Bogachenko, V. N. \& Shved, A. D. (1975). Thermophilic and thermotolerant methaneassimilating bacteria. Mikrobiologiia 44, 855-862 (in Russian).

Murrell, J. C., McDonald, I. R. \& Bourne, D. G. (1998). Molecular methods for the study of methanotroph ecology. FEMS Microbiol Ecol 27, 103-114.

Sambrook, J., Fritsch, E. F. \& Maniatis, T. (1989). Molecular Cloning: a Laboratory Manual, 2nd edn. Cold Spring Harbor, NY: Cold Spring Harbor Laboratory.

Sokolov, A. P. \& Trotsenko, Y. A. (1995). Methane consumption in (hyper)saline habitats of Crimea (Ukraine). FEMS Microbiol Ecol 18, 299-304.

Trotsenko, Y. A. \& Khmelenina, V. N. (2002). Biology of extremophilic and extremotolerant methanotrophs. Arch Microbiol 177, 123-131.

Van de Peer, Y. \& De Wachter, R. (1994). TREECON for Windows: a software package for the construction and drawing of evolutionary trees for the Microsoft Windows environment. Comput Appl Biosci $10,569-570$

Whittenbury, R., Phillips, K. C. \& Wilkinson, J. F. (1970). Enrichment, isolation and some properties of methane-utilizing bacteria. J Gen Microbiol 61, 205-218. 